\title{
Modulation of glycogen synthase kinase-3 $\beta$ following TRAIL combinatorial treatment in cancer cells
}

\author{
Sreevidya Santha ${ }^{1}$, Gantulga Davaakhuu ${ }^{1}$, Aninda Basu ${ }^{1}$, Rong Ke ${ }^{1}$, Subhasis Das ${ }^{1}$, \\ Ajay Rana ${ }^{1,2,3}$, Basabi Rana ${ }^{1,2,3}$ \\ ${ }^{1}$ Department of Surgery, Division of Surgical Oncology, University of Illinois at Chicago, Chicago, IL 60612, USA \\ ${ }^{2}$ University of Illinois Hospital and Health Sciences System Cancer Center, University of Illinois at Chicago, Chicago, IL 60612, USA \\ ${ }^{3}$ Jesse Brown VA Medical Center, Chicago, IL 60612, USA
}

Correspondence to: Basabi Rana, email: basrana@uic.edu

Keywords: GSK3 $\beta, A K T, P P A R Y, A M P K$, apoptosis-resistance

Received: July 26, $2016 \quad$ Accepted: August 29, 2016

Published: September 02, 2016

\section{ABSTRACT}

Glycogen Synthase Kinase-3 $\beta$ (GSK3 $\beta$ ) is a serine/threonine kinase, known to regulate various cellular processes including proliferation, differentiation, survival, apoptosis as well as TRAIL-resistance. Thus pathways that can modulate GSK3 $\beta$ axis are important targets for cancer drug development. Our earlier studies have shown that combinatorial treatment with Troglitazone (TZD) and TRAIL can induce apoptosis in TRAIL-resistant cancer cells. The current studies were undertaken to investigate whether GSK3 $\beta$ pathway was modulated during this apoptosis. Our results indicated an increase in inhibitory GSK3 $\beta^{\text {Ser9 }}$ phosphorylation during apoptosis, mediated via AKT. At a later time, however, TZD alone and TRAIL-TZD combination produced a dramatic reduction of GSK3 $\beta$ expression, which was abolished by cycloheximide. Luciferase assays with GSK3 $\beta$-luc promoter reporter showed that TZD can effectively antagonize GSK3 $\beta$ promoter activity. Since TZD is a ligand for transcription factor PPARY and can activate AMPK, we determined their roles on antagonism of GSK3 $\beta$. Knockdown of PPARy was unable to restore GSK3 $\beta$ expression or antagonize GSK3 $\beta^{\text {ser9 }}$ phosphorylation. Although pretreatment with Compound C (pharmacological inhibitor of AMPK) partially rescued GSK3 $\beta$ expression, knockdown of AMPKa1 or a2 alone or in combination were ineffective. These studies suggested a novel PPARY-AMPKindependent mechanism of targeting GSK3 $\beta$ by TZD, elucidation of which might provide newer insights to improve our understanding of TRAIL-resistance.

\section{INTRODUCTION}

Glycogen synthase kinase-3 (GSK-3) is a multifunctional serine/threonine kinase that has been implicated in regulating several fundamental processes including cell proliferation, differentiation, metabolism, survival and apoptosis [1], as well as various pathological conditions such as diabetes, oncogenesis and neurological diseases [2]. GSK3 derived its name from its phosphorylation activity toward glycogen synthase, thus linking it to glycogen metabolism. Since then, increasing research on GSK3 has significantly improved our understanding of this molecule. Two GSK3 genes $(\alpha$ and $\beta$ ) have been cloned in mammals with strong sequence conservation within the catalytic domain between the homologues [3]. Due to its profound role in neurodegeneration, the efficacy of GSK3 inhibitors in Alzheimer's disease have also been tested [4]. GSK3 is known to phosphorylate and regulate the activities of more than 40 proteins, many of which are transcription factors [5]. This indicates the potential contribution of this enzyme in regulating a variety of cellular functions. The regulation of GSK3 $\beta$ activity is not completely understood and is believed to be mediated via a combination of phosphorylation, localization and interaction with other proteins $[6,7]$. The major inhibitory phosphorylation is on Ser9 of GSK3 $\beta$ and Ser21 of GSK3 $\alpha[8,9]$ and can be phosphorylated by multiple upstream kinases including AKT [10].

In the cancer field, GSK-3 $\beta$ is commonly recognized as a putative tumor suppressor due to its well-established function as a repressor of $\beta$-catenin signaling [11] and 
phosphorylation-dependent down-regulation of cellcycle regulators cyclin D1 [12], cdc25 [13], and c-Myc [14]. Paradoxically, it can also promote cell survival and oppose apoptosis $[15,16]$. An involvement of GSK3 $\beta$ in mediating tumorigenic pathways is also indicated by its induced expression in various cancers including colon cancer [17], pancreatic cancer [18, 19], prostate cancer [20-22], and glioblastoma [23]. This notion is supported by recent studies suggesting an involvement of GSK3 $\beta$ in pancreatic cancer cell survival [24], dedifferentiation [19] as well as therapeutic resistance [25-27]. Similarly, GSK3 $\beta$ inhibition was shown to ameliorate apoptosis resistance in other types of cancer as well [28, 29]. A close connection of GSK $3 \beta$ in prostate cancer has been demonstrated earlier by the fact that increased cytoplasmic GSK3 $\beta$ correlated with the clinical stage and Gleason score in prostate tumor samples [30]. In addition, GSK3 $\beta$ was shown to positively regulate androgen receptor (AR) function $[31,20]$ and nuclear translocation [32]. An understanding of how GSK3 $\beta$ pathway is modulated during apoptotic signaling is thus important for the development of new and effective therapeutic approaches that can target GSK3 $\beta$.

In recent studies with TRAIL-resistant cancer cells, we have observed that treatment with a combination of TRAIL and PPAR $\gamma$ ligand Troglitazone (TZD) induces profound apoptosis compared to either agent alone [33]. The aim of the present study was to determine whether GSK $3 \beta$ pathway was modulated by this combination treatment and to elucidate the potential mechanism. Our results indicate that in TRAIL-resistant prostate cancer and hepatocellular carcinoma (HCC) cells, TRAIL and TZD treatment resulted in an induction of GSK $3 \beta^{\text {Ser9 }}$ phosphorylation (indicating inhibition) at an earlier stage during apoptosis. In addition, total GSK3 $\beta$ levels were significantly down-regulated by TZD alone and by TRAIL-TZD combination at a later stage that involved inhibition of transcription. This downregulation of GSK3 $\beta$ involved mechanisms independent of PPAR $\gamma$ and AMPK. In addition, although pharmacological inhibition was ineffective, knockdown of GSK $3 \alpha$ and to a lesser extent GSK $3 \beta$ seemed to promote apoptosis when treated with TRAIL-TZD combination.

\section{RESULTS}

\section{Combination treatment with TRAIL-TZD attenuates GSK3ß pathway in cancer cells}

To understand the status of GSK3 $\beta$ pathway during apoptosis following treatment with TRAILTZD combination, prostate cancer cells (LNCaP and DU145) were treated with TRAIL-TZD combination for different lengths of time and changes in GSK3 $\beta$ levels were compared. Although total GSK3 $\beta$ expression was unaffected initially, prolonged treatment with TRAIL-TZD resulted in a significant reduction of total GSK3 $\beta$ expression in both cell types (Figure 1A, 1B $24 \mathrm{hrs}$ ). Reduction of total GSK $3 \alpha$, however was more modest. Similar regulation of GSK3 $\beta$ in both LNCaP (AR dependent) and DU145 (AR independent) cells suggested that this might be occurring independent of AR signaling. In addition, we also observed an increase of pGSK $3 \beta^{\text {Ser9 }}$ levels, which preceded reduction of total GSK $3 \beta$ and coincided with the period of active apoptosis (Figure 1B). The concentrations of both TRAIL and TZD needed to inhibit total GSK3 $\beta$ expression optimally were determined next. These studies designed with increasing concentrations of each agent indicated that combination of $100 \mathrm{ng} / \mathrm{ml}$ TRAIL and 50-100 $\mu \mathrm{M}$ TZD produced maximal effects on total GSK3 $\beta$ expression (Figure 1C). Thus the remaining studies were carried out with this combination.

In order to determine whether this regulation of GSK $3 \beta$ is also present in other cancer cells, we determined the changes in GSK3 $\beta$ levels in hepatocellular carcinoma cells (Huh7) and pancreatic cancer cells (BXPC3). These also showed a dramatic reduction of total GSK3 $\beta$ and $\alpha$ expressions in Huh7 cells following treatment with TRAIL-TZD combination (Figure 2A). A similar time dependent reduction of total GSK $3 \beta$ and $\alpha$ was also observed in the BXPC3 cells (Figure 2B). These were also associated with an initial increase in the levels of pGSK $3 \beta^{\text {Ser9 }}$ in both cell types. These suggested that TRAIL-TZD-induced modulation of GSK3 $\beta$ pathway is present in various cancer cells and is a generalized event.

\section{Comparison of the effects of TRAIL and TZD alone or in combination in antagonizing GSK3 $\beta$}

To understand the relative contribution of TRAIL or TZD alone and their combination in modulating total GSK3 $\beta$ expression, cells were treated with either agent alone or in combination and the effect on GSK3 $\beta$ levels was estimated. These studies indicated that treatment with TZD alone resulted in a significant attenuation of total GSK3 $\beta$ expression, which was further potentiated by TRAIL-TZD combination (Figure 3A, 3B). Antagonism of GSK $3 \beta$ axis by TZD and TRAIL-TZD was also evident from the reduction of GSK3 $\beta$ downstream target Glycogen Synthase Ser641 phosphorylation (Figure 3B, pGS $S^{\text {Ser641 }}$ panel). To determine whether TRAIL-TZD induced any change in GSK3 $\beta$ localization, Immunofluorescence studies were designed. These showed that treatment with TZD alone or in combination with TRAIL significantly reduced cytoplasmic and nuclear GSK3 $\beta$ levels (Figure 3C). These suggested TZD to be a major modulator of GSK3 $\beta$ expression. 


\section{TZD inhibits total GSK3ß at a transcriptional} level

In an attempt to understand the mechanism how TZD regulates total GSK3 $\beta$, studies were undertaken to determine whether the effects were at a post-translational level. Pretreatment with protein synthesis inhibitor cycloheximide (CHX) showed that although TZD reduced total GSK3 $\beta$ expression significantly in the absence of CHX (Figure 4A, compare lanes 1\&3), it was unable to do so in the presence of CHX (compare lanes 5\&7). These suggested that TZD attenuated total GSK3 $\beta$ levels not at a post-translational step and most likely regulated it at a transcriptional level or via modulating mRNA stability.

A

\begin{tabular}{|c|c|c|c|c|c|c|c|c|}
\hline Cell Type & \multicolumn{8}{|c|}{ LNCaP } \\
\hline Time & \multicolumn{2}{|c|}{ 4hrs } & \multicolumn{2}{|c|}{$6 \mathrm{hrs}$} & \multicolumn{2}{|c|}{$8 \mathrm{hrs}$} & \multicolumn{2}{|c|}{ 24hrs } \\
\hline TZD & - & + & - & + & - & + & - & + \\
\hline TRAIL & - & + & - & + & - & + & - & + \\
\hline DMSO & + & - & + & - & + & - & + & - \\
\hline GSK3 $\beta \rightarrow$ & $\infty$ & $=$ & - & - & - & - & - & $=$ \\
\hline $\operatorname{GSK3} \alpha \rightarrow$ & - & - & - & - & - & - & - & - \\
\hline Cas3 & - & $\infty$ & & $=$ & 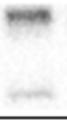 & $=$ & 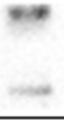 & 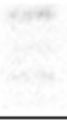 \\
\hline
\end{tabular}

B

\begin{tabular}{|c|c|c|c|c|c|c|c|c|}
\hline Cell Type & \multicolumn{8}{|c|}{ DU 145} \\
\hline Time & \multicolumn{2}{|c|}{ 4hrs } & \multicolumn{2}{|c|}{$6 \mathrm{hrs}$} & \multicolumn{2}{|c|}{$8 \mathrm{hrs}$} & \multicolumn{2}{|c|}{ 24hrs } \\
\hline TZD & - & + & - & + & - & + & - & + \\
\hline TRAIL & - & + & - & + & - & + & - & + \\
\hline DMSO & + & - & + & - & + & - & + & - \\
\hline $\mathrm{K} 3 \beta \rightarrow$ & $\infty$ & - & 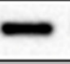 & - & - & - & - & - \\
\hline pGSK3 $\beta \underset{\text { Ser } 9}{\rightarrow}$ & $\overline{-}$ & $=$ & - & $\overline{ }$ & - & $\overline{ }$ & - & \\
\hline $\mathrm{K} 3 \alpha \rightarrow$ & - & - & - & - & - & - & - & \\
\hline Cas3 . & $=$ & 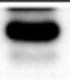 & $\vec{m}$ & 5 & $=$ & 5 & $\approx$ & - \\
\hline $\mathrm{PDH} \rightarrow$ & & & 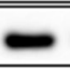 & & 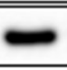 & & - & $=$ \\
\hline
\end{tabular}

\begin{tabular}{|c|c|c|c|c|c|c|c|c|c|}
\hline Cell Type & \multicolumn{9}{|c|}{ DU 145} \\
\hline Time & \multicolumn{9}{|c|}{ 24hrs } \\
\hline TZD conc $(\mu \mathrm{M})$ & - & 10 & 25 & 50 & 100 & \multicolumn{4}{|c|}{50} \\
\hline TRAIL conc. (ng/ml) & - & \multicolumn{4}{|c|}{100} & 25 & 50 & 100 & 150 \\
\hline DMSO & + & \multicolumn{4}{|c|}{-} & \multicolumn{4}{|c|}{-} \\
\hline Lane & 1 & 2 & 3 & 4 & 5 & 6 & 7 & 8 & 9 \\
\hline \multicolumn{10}{|l|}{ GSK3 $\beta \rightarrow$} \\
\hline \multicolumn{10}{|l|}{$\operatorname{GSK} 3 \alpha \rightarrow$} \\
\hline GAPDH $\rightarrow$ & & & & & & & $=$ & - & \\
\hline
\end{tabular}

Figure 1: Attenuation of GSK3 $\beta$ pathway by combination treatment with TRAIL and TZD in prostate cancer cells. (A) LNCaP and (B) DU 145 cells were treated with a combination of TRAIL (100 ng/ml) and Troglitazone (50 $\mu \mathrm{M})$ for different periods of time followed by Western Blot analysis with the indicated antibodies. (C) DU 145 cells were treated with increasing concentrations of TZD $(10,25,50,100 \mu \mathrm{M})$, or with increasing concentrations of TRAIL $(25,50,100,150 \mathrm{ng} / \mathrm{ml})$ for $24 \mathrm{hrs}$ followed by Western Blot analysis with the indicated antibodies. 
level by TZD, we determined next whether PPAR $\gamma$ played any role in modulating GSK $3 \beta$ expression. To understand the role of PPAR $\gamma$ on GSK3 $\beta$ expression, endogenous PPAR $\gamma$ expression was knocked down using the smart pool hPPAR $\gamma$-siRNA from Dharmacon. PPAR $\gamma$-siRNA reduced PPAR $\gamma$ expression significantly (Figure 5A, 5B, PPAR $\gamma$-siRNA lanes), but was unable to antagonize TZD or TRAIL-TZD-induced reduction of total GSK3 $\beta$ expression (Figure 5B, compare lanes 3\&4 with 7\&8). These studies also revealed that, TRAIL-TZD-mediated induction of $\mathrm{pGSK} 3 \beta^{\mathrm{Ser} 9}$ was independent of PPAR $\gamma$ (Figure 5A).
TZD-induced attenuation of GSK-3 $\beta$ is modulated by compound $C$ independent of AMPK

In recent studies we have demonstrated that TRAIL and TZD-combination can induce apoptosis in prostate cancer cells involving AMPK pathway [35]. Since TZD can also activate AMPK $[36,37]$, we determined any role of AMPK in attenuating GSK3 $\beta$ pathway by pretreating the cells with Compound $\mathrm{C}$ (a known inhibitor of AMPK), prior to TRAIL-TZD treatment. These results showed that TRAIL-TZD-induced attenuation of total
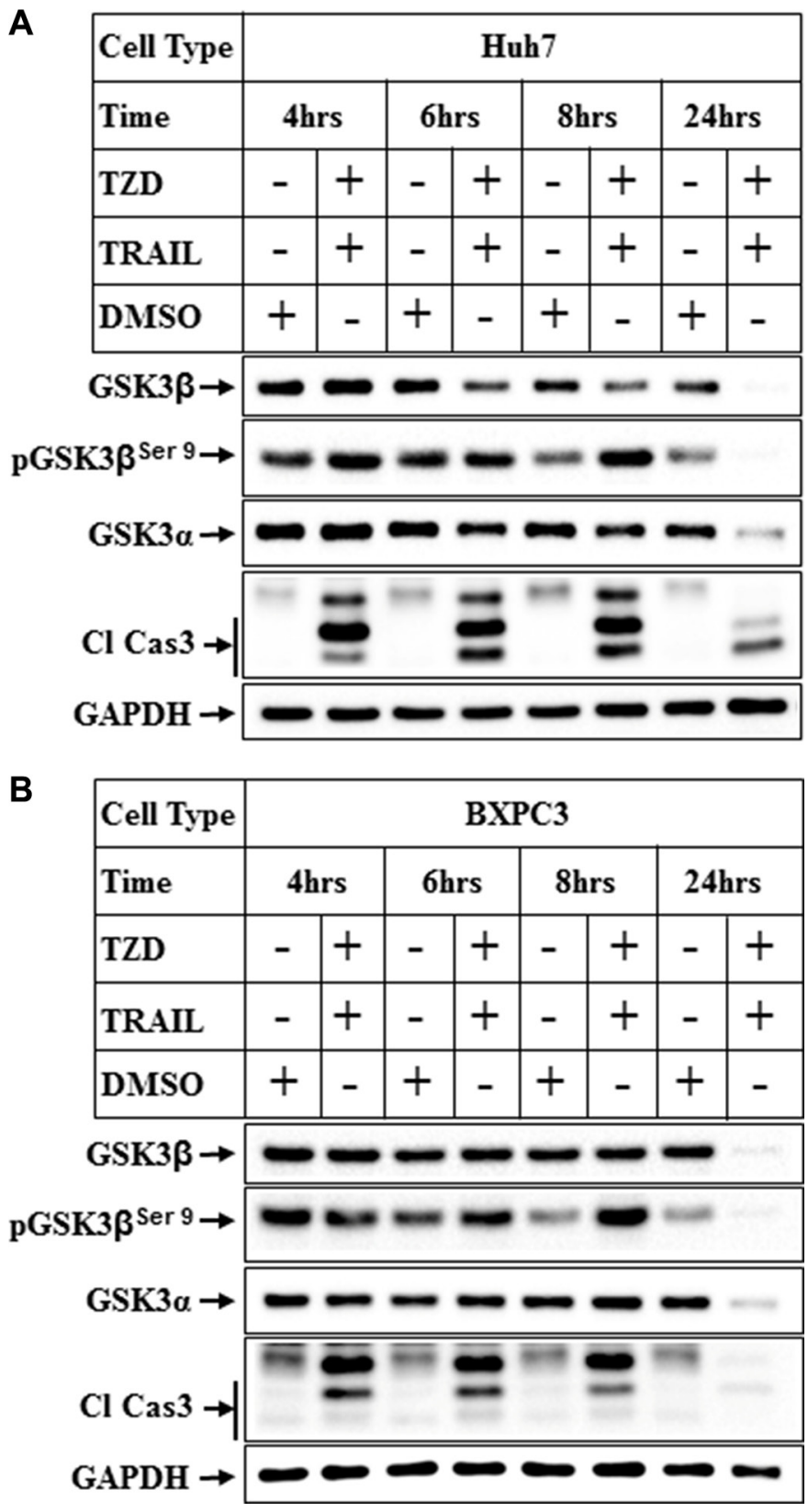

Figure 2: Attenuation of GSK3 $\beta$ pathway in various cancer cells by TRAIL and TZD treatment. (A) Huh7 and (B) BxPC3 cells were treated with a combination of TRAIL $(100 \mathrm{ng} / \mathrm{ml})$ and Troglitazone $(50 \mu \mathrm{M})$ for different periods of time followed by Western Blot analysis with the indicated antibodies. 
GSK3 $\beta$ expression at $24 \mathrm{hrs}$ can be partially antagonized by Compound $\mathrm{C}$ pretreatment in both Huh7 and DU145 cells (Figure 6A, 6B, compare lanes 5, 6 and 7, 8, GSK3 $\beta$ panel). Compound $\mathrm{C}$ also inhibited pACC ${ }^{\text {Ser79 }}$ (AMPK downstream target) in both cell types (Figure 6A, 6B), indicating the efficacy of the inhibitor. This suggested a potential involvement of AMPK in mediating total
GSK $3 \beta$ reduction. To confirm the participation of AMPK in mediating these effects, we determined the effect of TRAIL-TZD on GSK3 $\beta$ expression following knockdown of AMPK $\alpha$. Surprisingly, siRNA-mediated knockdown of AMPK $\alpha 1$ or $\alpha 2$ alone was unable to antagonize TZD or TRAIL-TZD-induced attenuation of GSK3 $\beta$ expression (Figure 7A, compare lanes 2, $5 \& 8$ and lanes 3, $6 \& 9$ ).

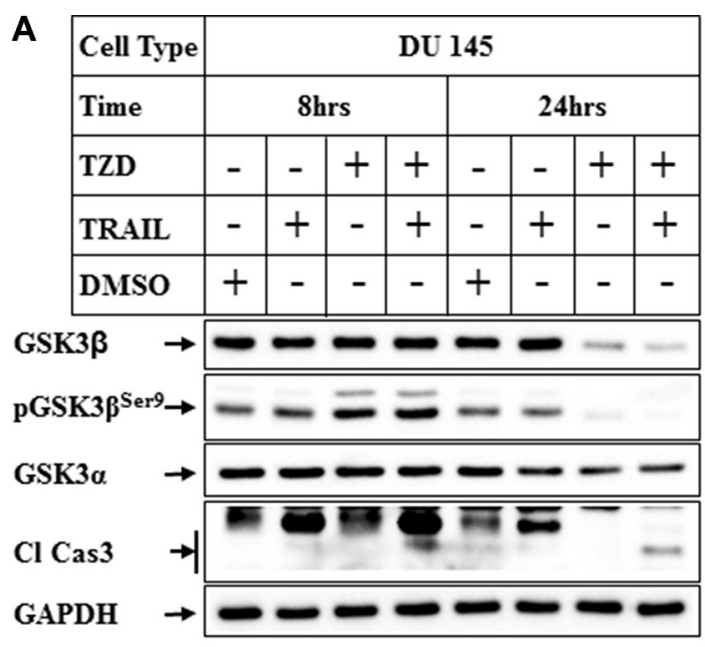

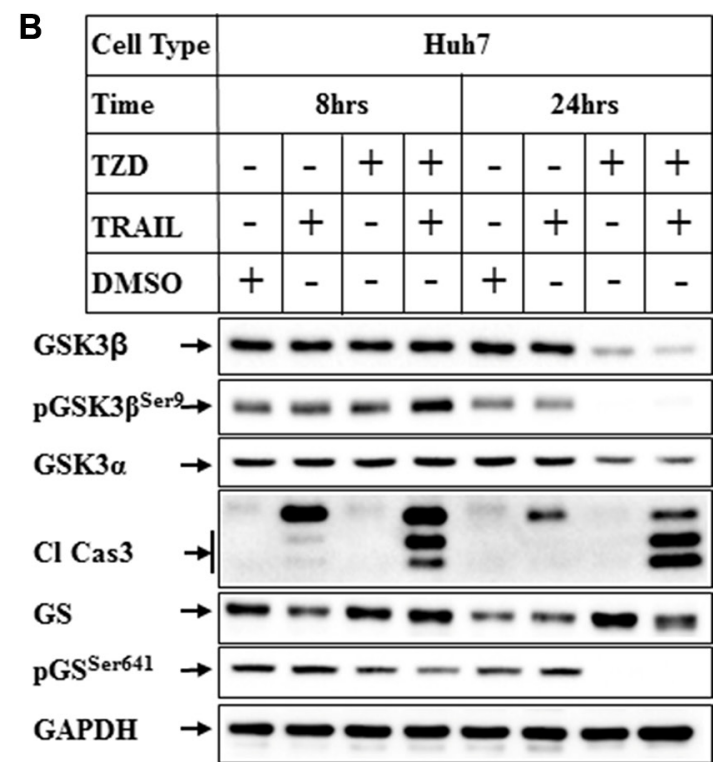

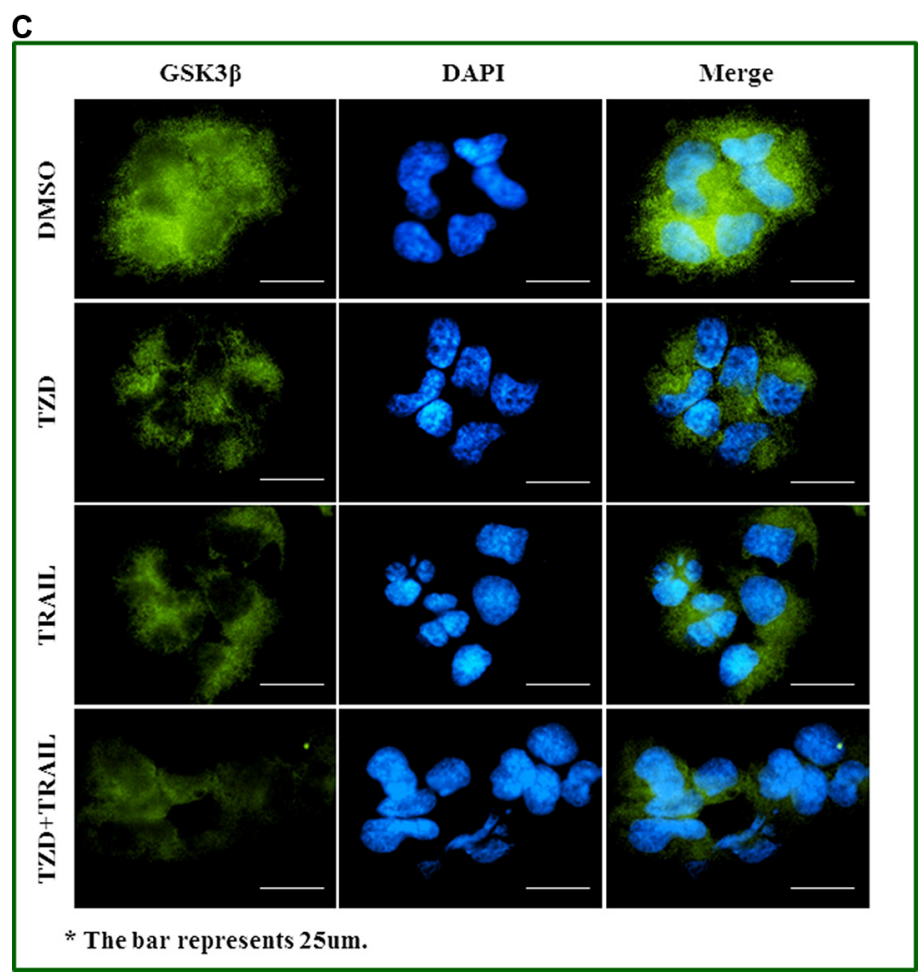

Figure 3: Comparison of the effects of TRAIL and TZD alone or in combination in antagonizing GSK3 $\beta$ pathway. (A) DU 145 and (B) Huh7 cells were treated with DMSO, TRAIL or TZD or a combination of TRAIL and TZD for 8 hrs and 24 hrs. Western Blot analyses were performed next with the indicated antibodies. (C) Huh7 cells plated in 4-well chamber slides were treated with DMSO, TZD, or TRAIL alone or in combination for $8 \mathrm{hrs}$. Immunofluorescence analysis with anti-GSK3 $\beta$ antibody was performed to detect endogenous GSK3 $\beta$ (green fluorescence). The nuclei were stained with DAPI (blue). The images were captured on a Nikon ECLIPSE Ti microscope, equipped with a digital camera (Nikon DS-Qi2) at 40× magnification. 
Knocking down AMPK $\alpha 1$ or $\alpha 2$ in combination also showed no effect in any of the cell types (Figure 7B, compare lanes 2, 4, $6 \& 8$ ). These suggested that GSK3 $\beta$ expression was regulated via a Compound $\mathrm{C}$ sensitive but AMPK-independent mechanism.

In these experiments we also observed that Compound $\mathrm{C}$ pretreatment was unable to antagonize TRAIL-TZD-induction of pGSK $3 \beta^{\text {Ser9 }}$ levels and rather showed minor induction, and a corresponding hyper-activation of AKT (Figure 6A, pGSK3 $\beta^{\text {Ser9 }}$ and pAKT $^{\text {Ser473 }}$ panels, compare lanes $\left.2 \& 4\right)$. To determine whether PI3Kinase and AKT was mediating GSK3 $\beta^{\text {Ser9 }}$ phosphorylation in TRAIL-TZD pathway, cells were pretreated with either the PI3Kinase inhibitor (LY294002) or the AKT inhibitor (AKT inhibitor VIII) followed by TRAIL-TZD treatment. LY294002 significantly antagonized basal and TRAIL-TZD-induced GSK3 $\beta^{\text {Ser9 }}$ phosphorylation levels which was fully antagonized by AKT inhibitor VIII (Figure 6C, compare lanes 2, 4 \& 6,
pGSK $3 \beta^{\text {Ser9 }}$ panel). pAKT ${ }^{\text {Ser473 }}$ or pAKT2 $2^{\text {Ser474 }}$ levels were completely abolished by LY294002, suggesting its efficacy in antagonizing PI3Kinase activation. These interesting results suggested that TRAIL-TZD likely increases GSK $3 \beta^{\text {Ser9 }}$ phosphorylation via a mechanism that involves AKT and upstream PI3Kinase pathways.

\section{Effect of GSK-3ß inhibition on TRAIL-TZD- induced apoptosis}

To understand whether antagonism of GSK3 $\beta$ was necessary to promote apoptosis, cells were pretreated with pharmacological inhibitors of GSK3 $\beta$ followed by treatment with TRAIL or TRAIL-TZD. Pretreatment with CHIR 99021, a specific inhibitor of GSK3 $\beta$ [38] produced no significant increase on TRAIL or TRAIL-TZD-induced apoptosis after $8 \mathrm{hrs}$ or $16 \mathrm{hrs}$ of treatment (Figure 8A and 8B). CHIR 99021, however, inhibited pGS ${ }^{\text {Ser641 }}$ levels, suggesting its efficacy in inhibiting GSK3$\beta$ activity.

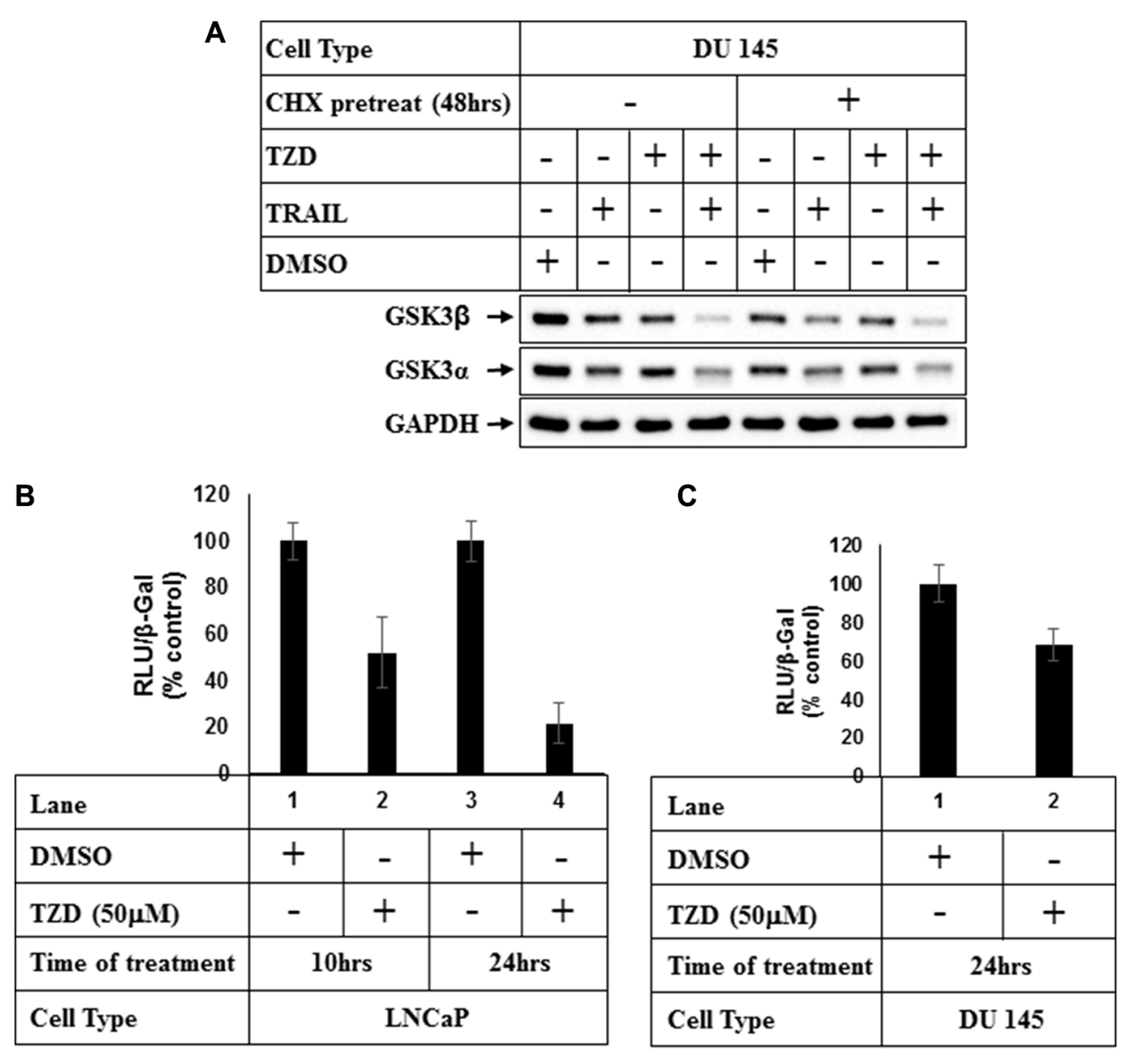

Figure 4: TZD treatment attenuates GSK3ß expression at a transcriptional level. (A) DU 145 cells were pretreated with $50 \mu \mathrm{g} / \mathrm{ml}$ Cycloheximide (CHX) for $48 \mathrm{hrs}$ and then with DMSO or TRAIL, TZD alone or in combination for an additional $24 \mathrm{hrs}$. At the end of incubation, cells were harvested and equal amounts of total protein were analyzed by Western Blots with the antibodies indicated.

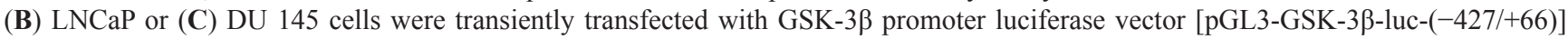
and $\beta$-Galactosidase ( $\beta$-Gal) vector for $48 \mathrm{hrs}$ followed by treatment with DMSO, or TZD for the indicated periods of time. Luciferase and $\beta$-galactosidase assays were carried out next and RLU/ $\beta$-Gal values were expressed as $\%$ control. The data in each set represent the mean $\pm \mathrm{SD}$ of three independent experiments. 
Similar results were obtained with two other inhibitors, GSK3 $\beta$ inhibitor VIII and Kenpaullone (Supplementary Figure S1 and S2). To confirm the role of GSK3 $\beta$ in mediating apoptosis or resistance, GSK3 $\beta$ or GSK3 $\alpha$ was knocked down first followed by treatment with TRAIL or TRAIL-TZD. Knockdown of GSK $3 \alpha$ and to a lesser extent GSK3 $\beta$ seemed to increase TRAIL-TZD-induced Caspase 3 and PARP cleavage, (Figure 8C, compare lanes 3, 6 \& 9). On the other hand, TRAIL-induced Caspase 3 and PARP cleavage was only marginally increased by GSK $3 \alpha$ knockdown, while knockdown of GSK $3 \beta$ produced no major effect (compare lanes 2, 5, 8). These suggested that antagonism of both isoforms are necessary to increase TRAIL-TZD-induced apoptosis, and GSK3 $\alpha$ seems to be important in TRAIL-induced apoptosis.

\section{DISCUSSION}

The serine/threonine kinase GSK3 $\beta$ plays important roles in the pathogenesis of a wide variety of diseases that include neurodegenerative diseases (e.g. Parkinson's Disease), inflammatory diseases and

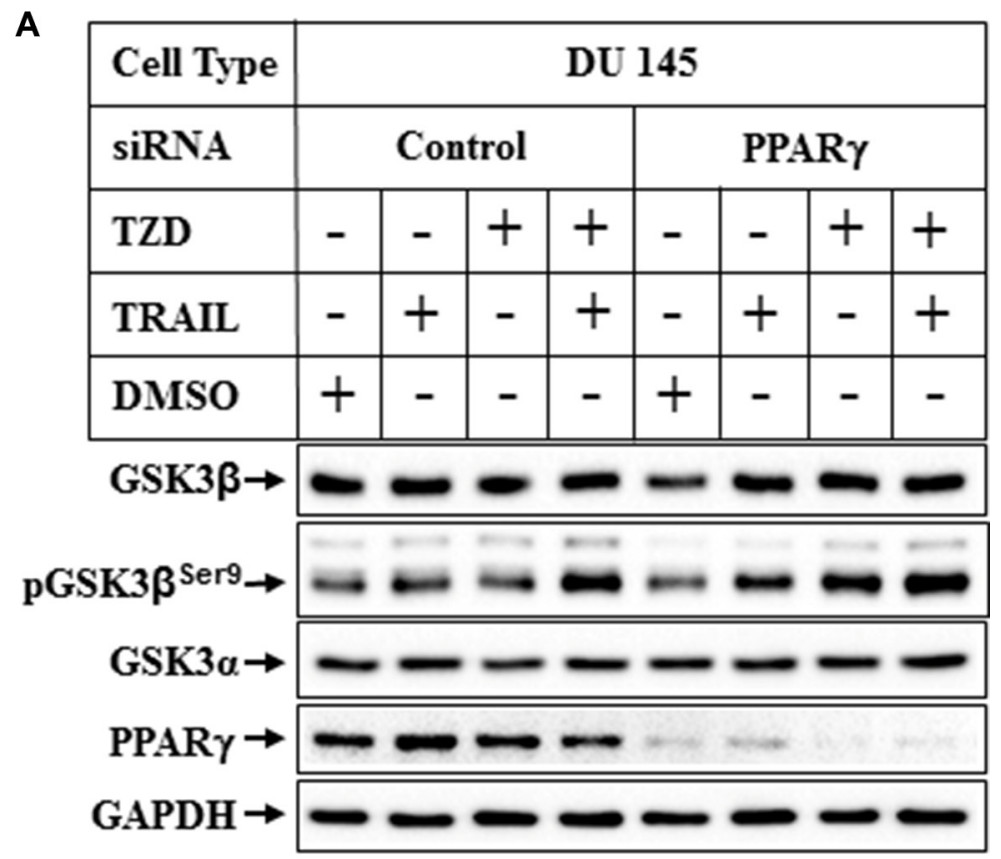

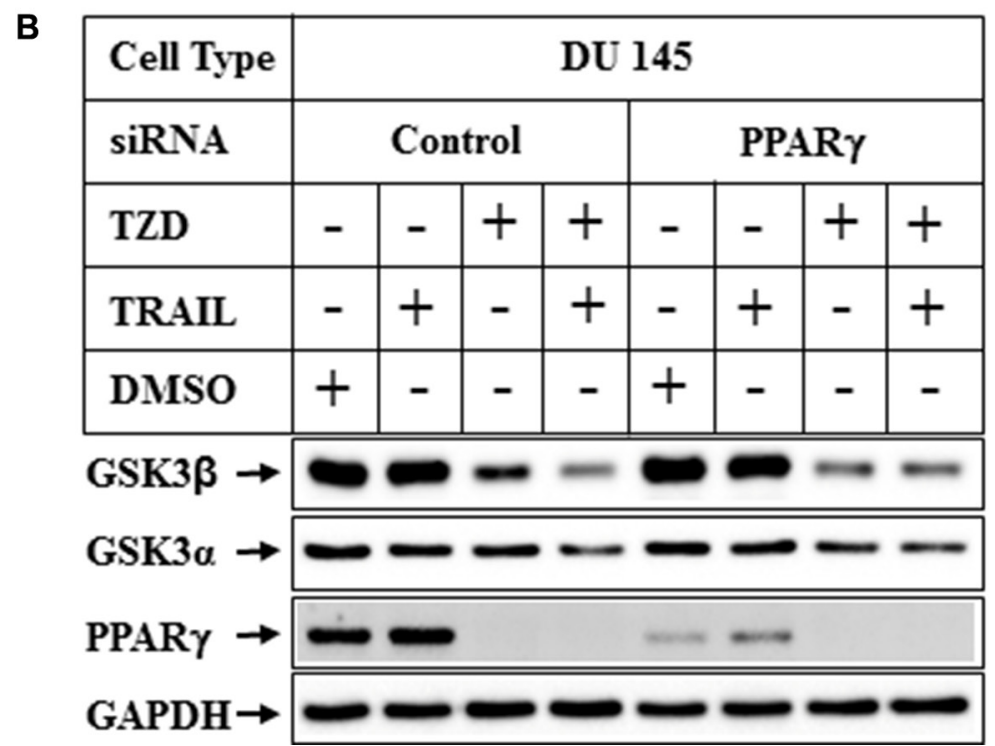

Figure 5: Effect of PPAR $\gamma$ knockdown on TRAIL-TZD-induced modulation of GSK3 $\beta$ pathway. Subconfluent DU 145 cells were transfected with either control-siRNA or PPAR $\gamma$-siRNA for $72 \mathrm{hrs}$ followed by treatment with TRAIL or TZD alone or in combination for $6 \mathrm{hrs}$ (A) or $24 \mathrm{hrs}$ (B). The samples were analyzed by Western blots with the antibodies indicated. 
cancer [39-41]. GSK3 $\beta$ expression is known to be induced in several cancer types, which include colon cancer [17], pancreatic cancer [18, 19], prostate cancer [20-22] and glioblastoma [23]. Increasing evidence points towards a pro-oncogenic role of GSK3 $\beta$ in various cancer types due to its effects in promoting cell proliferation and survival $[17,42]$. Particularly, in pancreatic cancer cells GSK3 $\beta$ pathway was associated with increased $\mathrm{NF} \kappa \mathrm{B}$ activity, increased cancer cell survival [24], tumor dedifferentiation [19] and tumor resistance $[25,26]$. There is also a strong evidence supporting a role of GSK3 $\beta$ in prostate cancer where it is involved in promoting androgen receptor function and nuclear translocation [20, 31, 32]. In addition, increased cytoplasmic GSK3 $\beta$ in prostate tumor samples correlated with the clinical stage and Gleason score [30]. While all these suggest that targeting GSK3 $\beta$ might be an important and effective means of controlling cancer progression, therapeutic options currently available are limited. This is because majority of the available pharmacological inhibitors of GSK $3 \beta$ have limited specificity and also target several other protein kinases [38].

In an attempt to overcome this limitation of GSK3 $\beta$ inhibitors, in the current study we aimed at elucidating the mechanism by which GSK3 $\beta$ expression can be
A

\begin{tabular}{|c|c|c|c|c|c|c|c|c|}
\hline Cell Type & \multicolumn{8}{|c|}{ Huh 7} \\
\hline Time & \multicolumn{4}{|c|}{ 8hrs } & \multicolumn{4}{|c|}{$24 \mathrm{hrs}$} \\
\hline Compound $\mathrm{C}$ & \multicolumn{2}{|c|}{-} & \multicolumn{2}{|c|}{+} & \multicolumn{2}{|c|}{ - } & \multicolumn{2}{|c|}{+} \\
\hline TRAIL+TZD & - & + & - & + & - & + & - & + \\
\hline DMSO & + & - & + & - & + & - & + & - \\
\hline GSK3 $\beta$ & - & - & 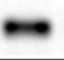 & - & - & - & - & - \\
\hline pGSK3 $\beta^{\text {Ser9 }} \rightarrow$ & - & - & $\cdots$ & $=$ & - & - & - & - \\
\hline pACC ${ }^{\text {Ser } 79} \rightarrow$ & - & - & - & $\infty$ & $\infty$ & - & - & $\longrightarrow$ \\
\hline $\mathrm{ACC}$ & 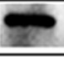 & - & $\cdots$ & - & - & $\cdots$ & - & $\cdots$ \\
\hline pAKT $^{\text {Ser473 } \rightarrow}$ & - & - & - & 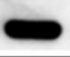 & 一 & - & - & - \\
\hline AKT & - & - & - & - & $\rightarrow$ & - & - & - \\
\hline GAPDH $\rightarrow$ & & $\longrightarrow$ & - & & - & - & $\longrightarrow$ & - \\
\hline
\end{tabular}

C

\begin{tabular}{|c|c|c|c|c|c|c|}
\hline Cell Type & \multicolumn{6}{|c|}{ Huh7 } \\
\hline $\begin{array}{l}\text { AKT Inhibitor } \\
\text { VIII }(20 \mu \mathrm{M})\end{array}$ & \multicolumn{2}{|c|}{ - } & \multicolumn{2}{|c|}{ - } & \multicolumn{2}{|c|}{+} \\
\hline $\begin{array}{c}\text { LY294002 } \\
(50 \mu \mathrm{M})\end{array}$ & \multicolumn{2}{|c|}{ - } & \multicolumn{2}{|c|}{+} & \multicolumn{2}{|c|}{ - } \\
\hline TRAIL+TZD & - & + & - & + & - & + \\
\hline DMSO & + & - & + & - & + & - \\
\hline GSK3 $\beta$ & - & - & - & - & - & - \\
\hline pGSK3 $^{\text {Ser9 }} \rightarrow$ & - & - & - & - & - & - \\
\hline pAKT $^{\text {Ser473 }} \rightarrow$ & - & - & & & & \\
\hline pAKT2 ${ }^{\text {Ser474 } \rightarrow}$ & - & - & & & & . \\
\hline AKT & - & - & - & - & - & - \\
\hline GAPDH & & 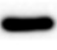 & - & 0 & - & - \\
\hline
\end{tabular}

B

\begin{tabular}{|c|c|c|c|c|c|c|c|c|}
\hline Cell Type & & & & & 145 & & & \\
\hline Time & & $8 \mathrm{~h}$ & & & & & hrs & \\
\hline Compound $\mathrm{C}$ & & - & & + & & - & - & \\
\hline TRAIL+TZD & - & + & - & + & - & + & - & + \\
\hline DMSO & + & - & + & - & + & - & + & - \\
\hline GSK3 $\beta$ & - & - & - & - & 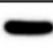 & - & $\longrightarrow$ & - \\
\hline $\mathrm{pACC}^{\mathrm{Ser} 79} \rightarrow$ & - & - & & & & - & & \\
\hline $\mathrm{ACC}$ & - & 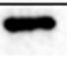 & $\ldots$ & - & 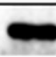 & $\sim$ & - & - \\
\hline GAPDH $\rightarrow$ & - & - & - & - & & & - & - \\
\hline
\end{tabular}

Figure 6: Effect of inhibition of AMPK and PI3K/AKT pathways on TRAIL-TZD-induced modulation of GSK3ß pathway. (A) Huh7 or (B) DU 145 cells were pretreated with $20 \mu \mathrm{M}$ Compound C for 24 hrs followed by treatment with DMSO or TRAIL-TZD combination for 8 hrs and 24 hrs. The results were analyzed by Western blots. (C) Huh7 cells were pretreated with PI3K inhibitor (LY294002) or AKT Inhibitor VIII for $1 \mathrm{hr}$ followed by TRAIL-TZD treatment for $8 \mathrm{hrs}$ and Western blot analyses. 
antagonized in cancer cells. Although TZD-mediated antagonism of GSK3 $\beta$ was reported earlier [43], those studies provided limited insight towards the mechanism involved. Our results show that treatment with a combination of TRAIL and TZD which induces potent apoptosis [35], also antagonized the expression of total GSK $3 \beta$ in various cancer cells. More in depth analysis showed that TZD alone can significantly attenuate GSK3 $\beta$ expression, which inhibited total GSK $3 \beta$ via antagonizing its transcription. Since TZD is a ligand of PPAR $\gamma$, we determined whether PPAR $\gamma$ played any role in this antagonism via designing siRNA-mediated knockdown experiments. Surprisingly, TZD-induced antagonism seemed to be PPAR $\gamma$-independent. This is supported by several earlier studies that have showed that TZD can antagonize expression of $\beta$-catenin [44], cyclin D1 [45], c-myc [46] independent of PPAR $\gamma$. Since TZD is known to activate AMPK and our earlier studies showed the involvement of AMPK pathway in TRAIL-TZD-induced apoptosis, we hypothesized that AMPK might be involved in regulating GSK3 $\beta$ expression. In fact, pretreatment with a pharmacological inhibitor of AMPK (Compound C) was capable of partially reversing the inhibitory effects of TRAIL-TZD on total GSK3 $\beta$ expression. However, these effects of Compound $\mathrm{C}$ seemed to be AMPKindependent, since knocking down AMPK $\alpha 1$ or $\alpha 2$ alone or in combination was unable to reverse the expression of GSK3 $\beta$ in the presence of TRAIL-TZD. Several studies have reported AMPK-independent effects of Compound C [47], which seems to involve antagonism of mTOR

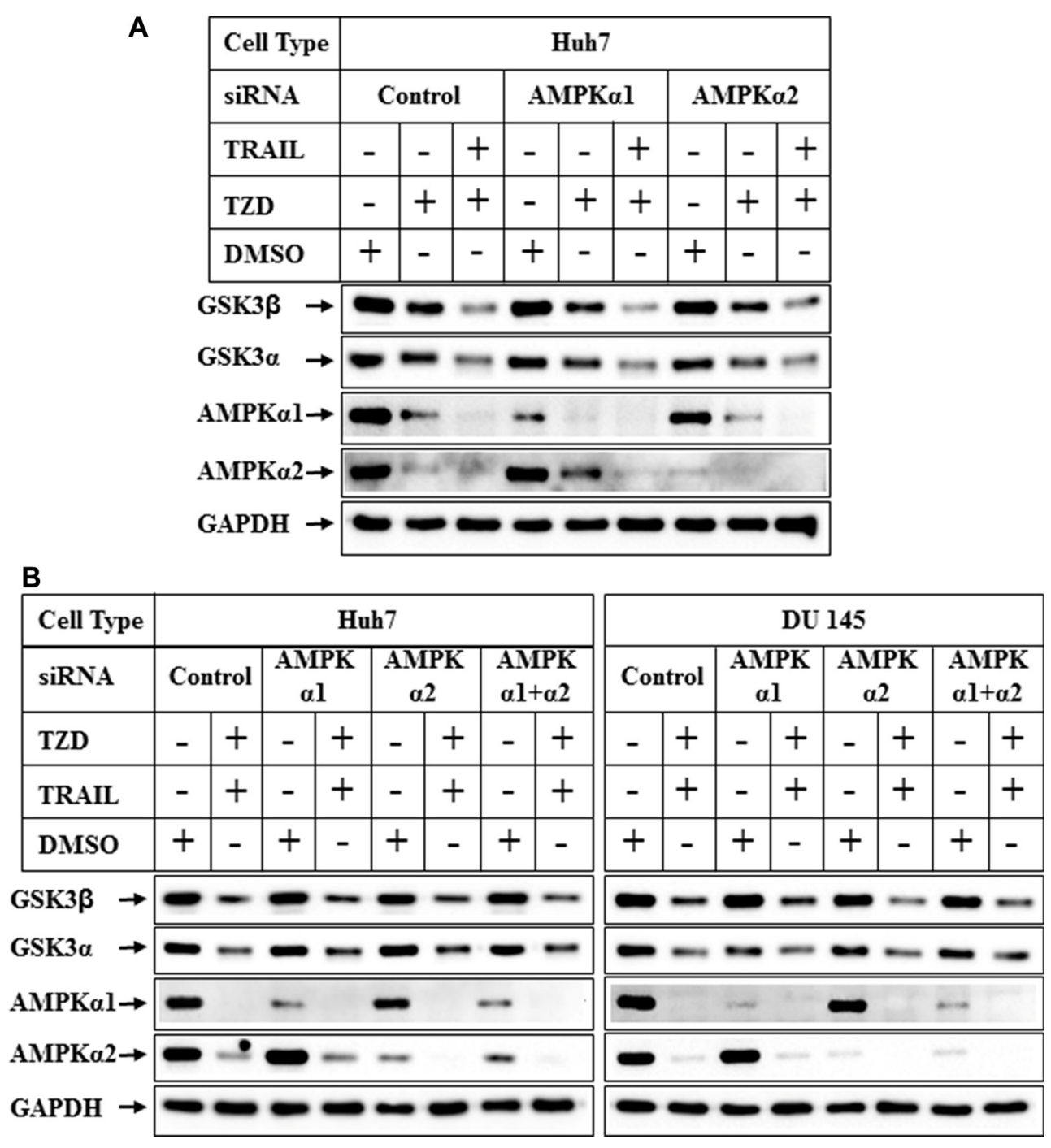

Figure 7: Effect of knockdown of AMPK $\alpha 1$ or $\alpha 2$ on TRAIL-TZD modulation of GSK3 pathway. (A) Subconfluent Huh7 cells were transiently transfected with either control-siRNA, or AMPK $\alpha 1$-siRNA or AMPK $\alpha 2$-siRNA separately for 72 hrs followed by treatment with DMSO, TZD or TRAIL-TZD combination for $24 \mathrm{hrs.} \mathrm{The} \mathrm{samples} \mathrm{were} \mathrm{analyzed} \mathrm{by} \mathrm{western} \mathrm{blots.} \mathrm{(B)} \mathrm{Huh7} \mathrm{and} \mathrm{DU}$ 145 cells were transiently transfected with either control-siRNA, AMPK $\alpha 1$-siRNA, AMPK $\alpha 2$-siRNA or a combination of AMPK $\alpha 1$ and AMPK $\alpha 2$-siRNA for $72 \mathrm{hrs}$. The cells were harvested following a treatment with DMSO or TRAIL-TZD combination for 24 hrs and analyzed by Western blots. 
pathway in $T$ cells [48] and multiple mechanisms in human gliomas [49]. It is unclear who the mediators are downstream of TZD or TRAIL-TZD that regulate GSK3 $\beta$ expression in the cancer cells. Earlier studies by Zhang et al. have shown that mutant K-Ras induces GSK3 $\beta$ transcription in pancreatic cancer cells via MAPK involving E-twenty six 2 (ETS2) transcription factor and p300 histone acetyltransferase [34]. Since TZD is known to inhibit the ETS pathway [50,51], it seems possible that the inhibitory effects of TZD on GSK3 $\beta$ might involve ETS transcription factors. More molecular approaches are needed to firmly establish this in TZD-GSK3 $\beta$ axis.
To understand whether GSK3 $\beta$ inhibition plays a major role in mediating TRAIL-TZD-induced apoptosis or increased TRAIL sensitivity in cancer cells, we pretreated cells with different pharmacological inhibitors of GSK3 $\beta$ CHIR 99021, GSK3 $\beta$ inhibitor VIII and Kenpaullone followed by treatment with TRAIL alone or a combination of TRAIL and TZD. These results showed that these inhibitors can successfully antagonize GSK3 $\beta$ pathway as indicated by the corresponding reduction of $\mathrm{pGS}^{\mathrm{Ser} 641}$ levels, but produced no effect on apoptosis. To validate these, we also studied the effect of knocking down either GSK3 $\alpha$ or GSK3 $\beta$ on TRAIL or TRAIL-TZD-induced apoptosis. In these studies,

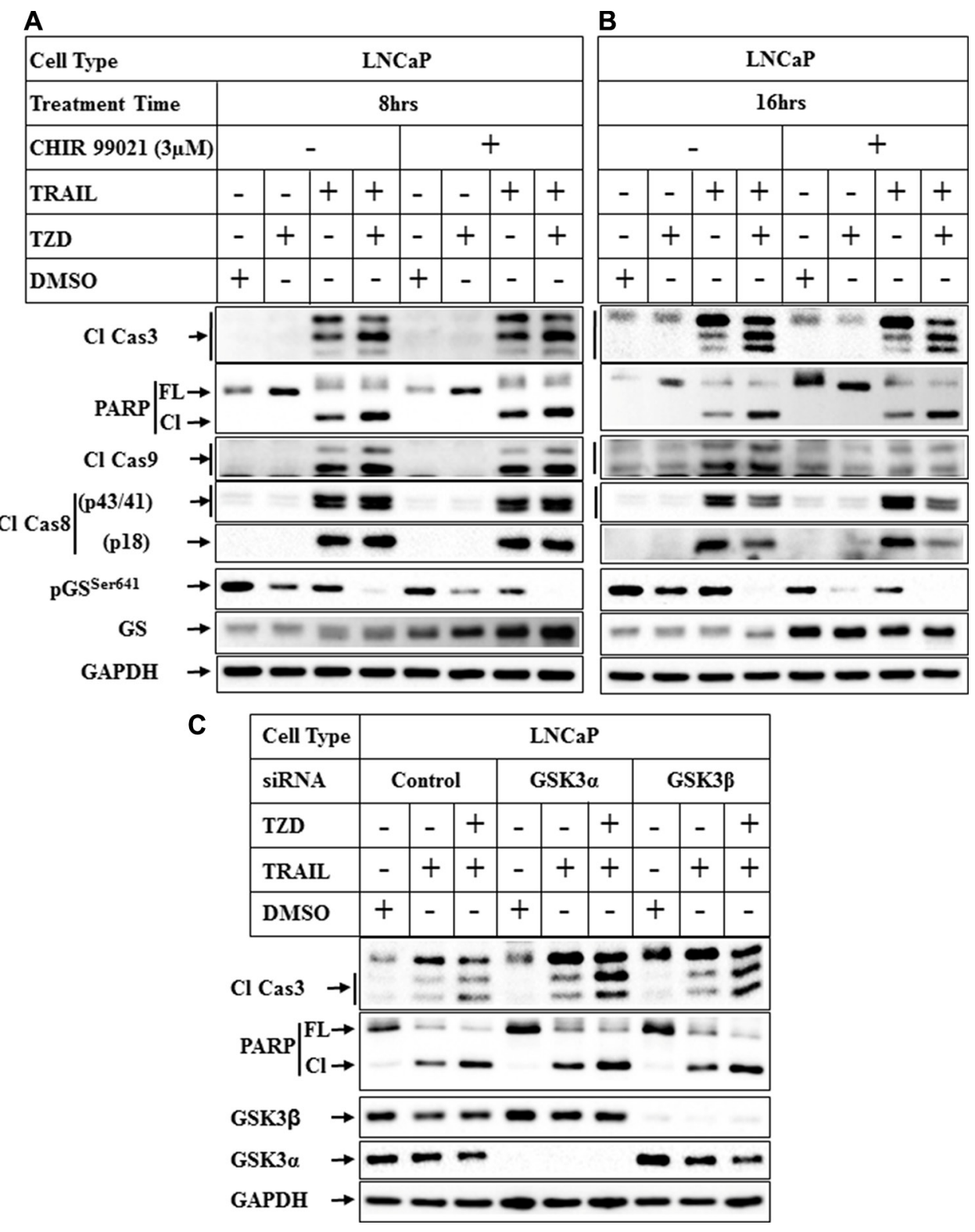

Figure 8: Effect of inhibition of GSK3 $\beta$ pathway on TRAIL-TZD-induced apoptosis. LNCaP cells were pretreated with $3 \mu \mathrm{M}$ CHIR 99021 for $1 \mathrm{hr}$ followed by treatment with DMSO, TZD, TRAIL or TRAIL-TZD combination for $8 \mathrm{hrs}$ (A) or $16 \mathrm{hrs}$ (B). Western blot analyses were performed next with the indicated antibodies. (C) Subconfluent LNCaP cells transiently transfected separately with control-siRNA, GSK3 $\alpha$-siRNA or GSK3 $\beta$-siRNA for 72 hrs followed by treatment with DMSO, TRAIL or TRAIL-TZD combination for $16 \mathrm{hrs}$. The samples were analyzed by Western blots. 
although knocking down GSK $3 \alpha$ and to a lesser extent GSK3 $\beta$ increased TRAIL-TZD-induced caspase 3 and PARP cleavage (indicating apoptosis), TRAIL-induced effects were potentiated only by GSK $3 \alpha$ knockdown. Similar observations were also reported by other investigators, where inhibition of GSK3 $\beta$ in pancreatic cancer cells significantly inhibited NFKB activity but failed to sensitize to gemcitabine [18]. In a separate study, Lithium-induced inhibition of GSK3 $\beta$ antagonized chemotherapy-induced apoptosis [52]. On the contrary, studies in colon cancer cells showed that either pharmacological inhibition or siRNA-mediated knockdown of GSK3 $\beta$ augmented TZD-induced reduction of $\mathrm{NF} \kappa \mathrm{B}$ activity, cell growth inhibition and apoptosis induction [43]. The reason behind these discrepancies is not quite clear, but indicates the complexity of GSK $3 \beta$ pathway which might be cancer-type specific and needs further analysis. In fact, GSK $3 \beta$ is known to have a paradoxical role in mediating intrinsic and extrinsic pathways of cellular apoptosis [53]. Various other studies have shown the involvement of GSK3 $\beta$ in specific pathways of apoptosis $[54,55,52]$. As described earlier and in view of multiple cellular effects regulated by GSK3 $\beta$, it is unclear at this point which major biological effects are mediated via inhibition of GSK3 $\beta$. It remains a possibility that TZD-mediated antagonism of GSK $3 \beta / \alpha$ axis might mediate a non-apoptotic form of cell death (or necroptosis) as was reported by others [56]. Necroptosis is a form of programmed necrosis that involves death receptors and specific signal transduction pathways mediated by receptor-interacting protein (RIP) kinases $[57,58]$. TZD has also been shown to be involved in necroptosis [59]. Despite this complexity, our studies provide a novel insight towards a pathway in which TZD can antagonize GSK3 $\beta$ expression and might be effective in targeting those cancers which rely on GSK $3 \beta$ activity for proliferation and survival.

\section{MATERIALS AND METHODS}

\section{Reagents and antibodies}

RPMI and DMEM, DMEM F12 tissue culture media, Lipofectamine 2000 and $\beta$-galactosidase assay kit were purchased from Invitrogen; the luciferase Assay Reagent from Promega (Madison, WI); Troglitazone, TRAIL and Cycloheximide (CHX) were purchased from EMD Biosciences (Gibbstown, NJ), Compound C, AKT Inhibitor VIII, LY294002, Kenpaullone and AR-A014418 were from EMD Millipore (Billerica, MA), CHIR 99021 was from Sigma (St. Louis, MO). The antibodies utilized were obtained from the following sources: poly (ADP-ribose) polymerase (PARP), caspase-3, GSK-3 $\beta$, phospho-GSK-3 $\beta^{\text {Ser9 }}$, GSK3 $\alpha$, AKT, pAKT ${ }^{\text {Ser473 }}, \mathrm{pAKT}^{\mathrm{Ser} 474}$, PPAR $\gamma$, AMPK $\alpha 1$ and $\alpha 2$, GS, pGS ${ }^{\text {Ser641 }}$ from Cell Signaling Technologies (Danvers, MA); GAPDH from Ambion Inc. (Austin, TX). The GSK3 $\beta$ promoter luciferase plasmid (pGL3-GSK-3 $\beta$-luc $(-427 /+66)$ was obtained from the laboratory of Dr. Daniel D. Billadeau, Mayo Clinic, Rochester, MN [34].

\section{Cell culture}

Human Prostate cancer cells (LNCaP, DU 145), pancreatic cancer cells (BxPC3) were obtained from ATCC and maintained in RPMI (LNCaP, DU 145) and DMEM (BxPC3) media supplemented with 10\% FBS, $100 \mathrm{IU} / \mathrm{ml}$ penicillin, and $100 \mu \mathrm{g} / \mathrm{ml}$ streptomycin. Human HCC cells (Huh7) were obtained as described [60] and grown in DMEM/F12 media. In TRAIL and TZD experiments, cells were treated with $100 \mathrm{ng} / \mathrm{ml}$ TRAIL or $50 \mu \mathrm{m}$ TZD (unless indicated otherwise) alone or in combination for various lengths of time followed by Western blot analysis. In the studies with $\mathrm{CHX}$, the cells were pretreated with $50 \mu \mathrm{g} / \mathrm{ml}$ of CHX for $48 \mathrm{hrs}$ followed by TRAIL-TZD for $24 \mathrm{hrs}$. For the inhibitor experiments, cells were pretreated for 1 hour or 24 hours with the respective inhibitors, followed by TRAIL-TZD treatment for various lengths of time.

\section{Luciferase assays}

Sub-confluent populations of cells were transiently transfected with GSK-3 $\beta$ luciferase promoter pGL3GSK-3 $\beta$-luc $(-427 /+66)$, along with $\beta$-galactosidase vector (to correct for transfection efficiency) utilizing Lipofectamine-2000 as per the manufacturer's instructions. After 24 hours of recovery in the growth medium, the cells were treated with TRAIL-TZD for various lengths of time; the cells were harvested after treatment and luciferase and $\beta$-galactosidase assays were performed as described earlier [61]. Each transfection was performed in triplicate, and each experiment was repeated at least twice. Luciferase and $\beta$-galactosidase $(\beta$-gal) assays were performed using a luminometer (Berthold Technologies, Centro XS ${ }^{3}$ LB 960) and a plate reader (Power Wave XS, Biotek), respectively. The results obtained were calculated as the ratio of relative light units (RLU) to $\beta$-gal values (RLU/ $\beta$-gal) and expressed as the $\%$ increase compared with controls.

\section{Small interference RNA (siRNA)}

siRNA smart pool against hPPAR $\gamma(\mathrm{L}-003436-00)$, hAMPK $\alpha 1$ (L-005027-00), hAMPK $\alpha 2$ (L-005361-00), hGSK3 $\beta$ (L-003010-00) and hGSK3 $\alpha$ (L-003009-00) were purchased from Dharmacon (Lafayette, $\mathrm{CO}$ ). A negative control siRNA from Ambion Inc. (Austin, TX) was used as control siRNA. siRNA transfection was performed using Lipofectamine 2000 as per the manufacturer's instructions. Briefly, subconfluent cells plated in $35 \mathrm{~mm}$ plates were transfected with $50 \mathrm{nM}$ of either control siRNA or target protein-siRNA for $24 \mathrm{~h}$ followed by recovery in serum containing medium. The transfected cells were treated after 72 hours of transfection with either DMSO or TRAIL or TZD alone or in combination for various lengths of time followed by western blot analysis. 


\section{Western blot analysis}

Western blot analysis was performed utilizing procedures described previously $[60,62]$. Briefly, equal amounts of total cell extracts were fractionated by SDSPAGE, transferred to PVDF membranes, and subjected to Western blot analysis utilizing various antibodies.

\section{Immunofluorescence microscopy}

Immunofluorescence microscopy was performed as reported earlier [63]. Briefly, Huh7 cells plated in 4-well chamber slides were treated with DMSO, TZD, or TRAIL alone or in combination for $8 \mathrm{hrs}$ and fixed with $4 \%$ paraformaldehyde in $0.1 \mathrm{M}$ PBS, $\mathrm{pH} 7.4$ and permeabilized with $0.1 \%$ Triton X-100 in $0.1 \mathrm{M}$ PBS. Rabbit-anti GSK $3 \beta$ antibody and fluorochrome-conjugated goat anti-rabbit antibody was used as primary and secondary antibodies respectively. They were also stained with 4,6-diamidino-2-phenylindole dihydrochloride (DAPI) to show the nucleus. Images were captured on a Nikon ECLIPSE Ti microscope, equipped with a digital camera (Nikon DS-Qi2) at $40 \times$ magnification.

\section{Abbreviations}

AMPK: AMP-activated protein kinase; AR: Androgen Receptor; $\beta$-Gal: $\beta$-galactosidase; CHX: Cycloheximide; GS: Glycogen Synthase; GSK3 $\alpha$ : Glycogen Synthase Kinase-3 alpha; GSK3ß: Glycogen Synthase Kinase-3 beta; HCC: Hepatocellular carcinoma; mTOR: Mammalian Target of Rapamycin; NFkB: Nuclear Factor $\kappa B$; PARP: Poly (ADP-ribose) Polymerase; PPAR $\gamma$ : Peroxisome Proliferator-activated Receptor gamma; RLU: Relative light units; siRNA: Small Interference RNA; TRAIL: Tumor Necrosis Factor-related Apoptosisinducing Ligand; TZD: Troglitazone.

\section{ACKNOWLEDGMENTS}

We thank Dr. Daniel D. Billadeau, Mayo Clinic, Rochester, MN for providing the GSK3 $\beta$ promoter

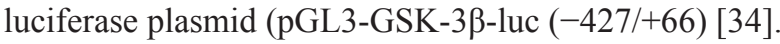

\section{CONFLICTS OF INTEREST}

The authors declare no conflicts of interest related to the study.

\section{GRANT SUPPORT}

This work was supported by the National Institutes of Health grants CA178063 (to B.R.) and CA176846 (to A.R.), Department of Defense Award W81XWH-10-1-0195 (to B. R.), and the Veterans Affairs Merit Award grants BX003296 (to B. R.) and BX002703, BX002355 (to A. R.).

\section{REFERENCES}

1. Kaidanovich-Beilin O, Woodgett JR. GSK-3: Functional Insights from Cell Biology and Animal Models. Front Mol Neurosci. 2011; 4:40.

2. Jope RS, Johnson GV. The glamour and gloom of glycogen synthase kinase-3. Trends Biochem Sci. 2004; 29:95-102.

3. Woodgett JR. Judging a protein by more than its name: GSK-3. Sci STKE. 2001; 2001:re12.

4. Bhat RV, Budd Haeberlein SL, Avila J. Glycogen synthase kinase 3: a drug target for CNS therapies. J Neurochem. 2004; 89:1313-1317.

5. Sutherland C. What Are the bona fide GSK3 Substrates? Int J Alzheimers Dis. 2011; 2011:505607.

6. McManus EJ, Sakamoto K, Armit LJ, Ronaldson L, Shpiro N, Marquez R, Alessi DR. Role that phosphorylation of GSK3 plays in insulin and Wnt signalling defined by knockin analysis. EMBO J. 2005; 24:1571-1583.

7. Taelman VF, Dobrowolski R, Plouhinec JL, Fuentealba LC, Vorwald PP, Gumper I, Sabatini DD, De Robertis EM. Wnt signaling requires sequestration of glycogen synthase kinase 3 inside multivesicular endosomes. Cell. 2010; 143:1136-1148.

8. Sutherland C, Leighton IA, Cohen P. Inactivation of glycogen synthase kinase- 3 beta by phosphorylation: new kinase connections in insulin and growth-factor signalling. Biochem J. 1993; 296:15-19.

9. Sutherland C, Cohen P. The alpha-isoform of glycogen synthase kinase- 3 from rabbit skeletal muscle is inactivated by $\mathrm{p} 70$ S6 kinase or MAP kinase-activated protein kinase-1 in vitro. FEBS Lett. 1994; 338:37-42.

10. Cross DA, Alessi DR, Cohen P, Andjelkovich M, Hemmings BA. Inhibition of glycogen synthase kinase-3 by insulin mediated by protein kinase B. Nature. 1995; 378:785-789.

11. Rubinfeld B, Albert I, Porfiri E, Fiol C, Munemitsu S, Polakis P. Binding of GSK3beta to the APC-beta-catenin complex and regulation of complex assembly. Science. 1996; 272:1023-1026.

12. Diehl JA, Cheng M, Roussel MF, Sherr CJ. Glycogen synthase kinase-3beta regulates cyclin D1 proteolysis and subcellular localization. Genes Dev. 1998; 12:3499-3511.

13. Kang T, Wei Y, Honaker Y, Yamaguchi H, Appella E, Hung MC, Piwnica-Worms H. GSK-3 beta targets Cdc25A for ubiquitin-mediated proteolysis, and GSK-3 beta inactivation correlates with $\mathrm{Cdc} 25 \mathrm{~A}$ overproduction in human cancers. Cancer Cell. 2008; 13:36-47.

14. Lutterbach B, Hann SR. Hierarchical phosphorylation at $\mathrm{N}$-terminal transformation-sensitive sites in c-Myc protein is regulated by mitogens and in mitosis. Mol Cell Biol. 1994; 14:5510-5522.

15. Hoeflich KP, Luo J, Rubie EA, Tsao MS, Jin O, Woodgett JR. Requirement for glycogen synthase kinase3 beta in cell survival and NF-kappaB activation. Nature. 2000; 406:86-90. 
16. Rottmann S, Wang Y, Nasoff M, Deveraux QL, Quon KC. A TRAIL receptor-dependent synthetic lethal relationship between MYC activation and GSK3beta/FBW7 loss of function. Proc Natl Acad Sci USA. 2005; 102:15195-15200.

17. Shakoori A, Ougolkov A, Yu ZW, Zhang B, Modarressi MH, Billadeau DD, Mai M, Takahashi Y, Minamoto $T$. Deregulated GSK3beta activity in colorectal cancer: its association with tumor cell survival and proliferation. Biochem Biophys Res Commun. 2005; 334:1365-1373.

18. Mamaghani S, Patel S, Hedley DW. Glycogen synthase kinase-3 inhibition disrupts nuclear factor-kappaB activity in pancreatic cancer, but fails to sensitize to gemcitabine chemotherapy. BMC cancer. 2009; 9:132.

19. Ougolkov AV, Fernandez-Zapico ME, Bilim VN, Smyrk TC, Chari ST, Billadeau DD. Aberrant nuclear accumulation of glycogen synthase kinase-3beta in human pancreatic cancer: association with kinase activity and tumor dedifferentiation. Clinical cancer research. 2006; 12:5074-5081.

20. Liao X, Thrasher JB, Holzbeierlein J, Stanley S, Li B. Glycogen synthase kinase-3beta activity is required for androgen-stimulated gene expression in prostate cancer. Endocrinology. 2004; 145:2941-2949.

21. Rinnab L, Schutz SV, Diesch J, Schmid E, Kufer R, Hautmann RE, Spindler KD, Cronauer MV. Inhibition of glycogen synthase kinase-3 in androgen-responsive prostate cancer cell lines: are GSK inhibitors therapeutically useful? Neoplasia. 2008; 10:624-634.

22. Zhu Q, Yang J, Han S, Liu J, Holzbeierlein J, Thrasher JB, Li B. Suppression of glycogen synthase kinase 3 activity reduces tumor growth of prostate cancer in vivo. Prostate. 2011; 71:835-845.

23. Miyashita K, Kawakami K, Nakada M, Mai W, Shakoori A, Fujisawa H, Hayashi Y, Hamada J, Minamoto T. Potential therapeutic effect of glycogen synthase kinase 3beta inhibition against human glioblastoma. Clin Cancer Res. 2009; 15:887-897.

24. Ougolkov AV, Fernandez-Zapico ME, Savoy DN, Urrutia RA, Billadeau DD. Glycogen synthase kinase3beta participates in nuclear factor kappaB-mediated gene transcription and cell survival in pancreatic cancer cells. Cancer Res. 2005; 65:2076-2081.

25. Kitano A, Shimasaki T, Chikano Y, Nakada M, Hirose M, Higashi T, Ishigaki Y, Endo Y, Takino T, Sato H, Sai Y, Miyamoto K, Motoo Y, et al. Aberrant glycogen synthase kinase 3 beta is involved in pancreatic cancer cell invasion and resistance to therapy. PLoS One. 2013; 8:e55289.

26. Mamaghani S, Simpson CD, Cao PM, Cheung M, Chow S, Bandarchi B, Schimmer AD, Hedley DW. Glycogen Synthase Kinase-3 Inhibition Sensitizes Pancreatic Cancer Cells to TRAIL-Induced Apoptosis. PLoS One. 2012; 7:e41102.

27. Zhang JS, Herreros-Villanueva M, Koenig A, Deng Z, de Narvajas AA, Gomez TS, Meng X, Bujanda L, Ellenrieder V, Li XK, Kaufmann SH, Billadeau DD.
Differential activity of GSK-3 isoforms regulates NFkappaB, TRAIL- or TNFalpha induced apoptosis in pancreatic cancer cells. Cell Death Dis. 2014; 5:e1142.

28. Mayes PA, Dolloff NG, Daniel CJ, Liu JJ, Hart LS, Kuribayashi K, Allen JE, Jee DI, Dorsey JF, Liu YY, Dicker DT, Brown JM, Furth EE, et al. Overcoming hypoxia-induced apoptotic resistance through combinatorial inhibition of GSK-3beta and CDK1. Cancer Res. 2011; 71:5265-5275.

29. Liao X, Zhang L, Thrasher JB, Du J, Li B. Glycogen synthase kinase-3beta suppression eliminates tumor necrosis factor-related apoptosis-inducing ligand resistance in prostate cancer. Mol Cancer Ther. 2003; 2:1215-1222.

30. Li R, Erdamar S, Dai H, Sayeeduddin M, Frolov A, Wheeler TM, Ayala GE. Cytoplasmic accumulation of glycogen synthase kinase-3beta is associated with aggressive clinicopathological features in human prostate cancer. Anticancer Res. 2009; 29:2077-2081.

31. Mazor M, Kawano Y, Zhu H, Waxman J, Kypta RM. Inhibition of glycogen synthase kinase-3 represses androgen receptor activity and prostate cancer cell growth. Oncogene. 2004; 23:7882-7892.

32. Schutz SV, Cronauer MV, Rinnab L. Inhibition of glycogen synthase kinase-3beta promotes nuclear export of the androgen receptor through a CRM1-dependent mechanism in prostate cancer cell lines. J Cell Biochem. 2010; 109:1192-1200.

33. Senthivinayagam S, Mishra P, Paramasivam SK, Yallapragada S, Chatterjee M, Wong L, Rana A, Rana B. Caspase-mediated Cleavage of \{beta\}-Catenin Precedes Drug-induced Apoptosis in Resistant Cancer Cells. J Biol Chem. 2009; 284:13577-13588.

34. Zhang JS, Koenig A, Harrison A, Ugolkov AV, FernandezZapico ME, Couch FJ, Billadeau DD. Mutant K-Ras increases GSK-3beta gene expression via an ETS-p300 transcriptional complex in pancreatic cancer. Oncogene. 2011; 30:3705-3715.

35. Santha S, Viswakarma N, Das S, Rana A, Rana B. Tumor Necrosis Factor-related Apoptosis-inducing Ligand (TRAIL)-Troglitazone-induced Apoptosis in Prostate Cancer Cells Involve AMP-activated Protein Kinase. J Biol Chem. 2015; 290:21865-21875.

36. LeBrasseur NK, Kelly M, Tsao TS, Farmer SR, Saha AK, Ruderman NB, Tomas E. Thiazolidinediones can rapidly activate AMP-activated protein kinase in mammalian tissues. Am J Physiol Endocrinol Metab. 2006; 291:E175-181.

37. Xiang X, Saha AK, Wen R, Ruderman NB, Luo Z. AMPactivated protein kinase activators can inhibit the growth of prostate cancer cells by multiple mechanisms. Biochem Biophys Res Commun. 2004; 321:161-167.

38. Bain J, Plater L, Elliott M, Shpiro N, Hastie CJ, McLauchlan H, Klevernic I, Arthur JS, Alessi DR, Cohen P. The selectivity of protein kinase inhibitors: a further update. Biochem J. 2007; 408:297-315. 
39. Beurel E, Grieco SF, Jope RS. Glycogen synthase kinase-3 (GSK3): regulation, actions, and diseases. Pharmacol Ther. 2015; 148:114-131.

40. Golpich M, Amini E, Hemmati F, Ibrahim NM, Rahmani B, Mohamed Z, Raymond AA, Dargahi L, Ghasemi R, Ahmadiani A. Glycogen synthase kinase-3 beta (GSK3beta) signaling: Implications for Parkinson's disease. Pharmacol Res. 2015; 97:16-26.

41. Domoto T, Pyko IV, Furuta T, Miyashita K, Uehara M, Shimasaki T, Nakada M, Minamoto T. Glycogen synthase kinase-3beta is a pivotal mediator of cancer invasion and resistance to therapy. Cancer Sci. 2016.

42. Cao Q, Lu X, Feng YJ. Glycogen synthase kinase-3beta positively regulates the proliferation of human ovarian cancer cells. Cell Res. 2006; 16:671-677.

43. Ban JO, Kwak DH, Oh JH, Park EJ, Cho MC, Song HS, Song MJ, Han SB, Moon DC, Kang KW, Hong JT. Suppression of NF-kappaB, GSK-3beta is involved in colon cancer cell growth inhibition by the PPAR agonist troglitazone. Chem Biol Interact. 2010; 188:75-85.

44. Wei S, Lin LF, Yang CC, Wang YC, Chang GD, Chen H, Chen CS. Thiazolidinediones modulate the expression of betacatenin and other cell-cycle regulatory proteins by targeting the F-box proteins of Skp1-Cul1-F-box protein E3 ubiquitin ligase independently of peroxisome proliferator-activated receptor gamma. Mol Pharmacol. 2007; 72:725-733.

45. Wei S, Yang HC, Chuang HC, Yang J, Kulp SK, Lu PJ, Lai MD, Chen CS. A novel mechanism by which thiazolidinediones facilitate the proteasomal degradation of cyclin D1 in cancer cells. J Biol Chem. 2008; 283:26759-26770.

46. Akinyeke TO, Stewart LV. Troglitazone suppresses c-Myc levels in human prostate cancer cells via a PPARgammaindependent mechanism. Cancer Biol Ther. 2011; 11: 1046-1058.

47. Emerling BM, Viollet B, Tormos KV, Chandel NS. Compound $\mathrm{C}$ inhibits hypoxic activation of HIF-1 independent of AMPK. FEBS Lett. 2007; 581:5727-5731.

48. Rao E, Zhang Y, Li Q, Hao J, Egilmez NK, Suttles J, Li B. AMPK-dependent and independent effects of AICAR and compound $\mathrm{C}$ on T-cell responses. Oncotarget. 2016; 7:33783-95. doi: 10.18632/oncotarget.9277.

49. Liu X, Chhipa RR, Nakano I, Dasgupta B. The AMPK inhibitor compound $\mathrm{C}$ is a potent AMPK-independent antiglioma agent. Mol Cancer Ther. 2014; 13:596-605.

50. Kitamura S, Miyazaki Y, Hiraoka S, Toyota M, Nagasawa Y, Kondo S, Kiyohara T, Shinomura Y, Matsuzawa Y. PPARgamma inhibits the expression of c-MET in human gastric cancer cells through the suppression of Ets. Biochem Biophys Res Commun. 1999; 265:453-456.

51. Kotake D, Hirasawa N. Activation of a retinoic acid receptor pathway by thiazolidinediones induces production of vascular endothelial growth factor/vascular permeability factor in OP9 adipocytes. Eur J Pharmacol. 2013; 707:95-103.
52. Beurel E, Kornprobst M, Blivet-Van Eggelpoel MJ, RuizRuiz C, Cadoret A, Capeau J, Desbois-Mouthon C. GSK3beta inhibition by lithium confers resistance to chemotherapyinduced apoptosis through the repression of CD95 (Fas/ APO-1) expression. Exp Cell Res. 2004; 300:354-364.

53. Beurel E, Jope RS. The paradoxical pro- and anti-apoptotic actions of GSK3 in the intrinsic and extrinsic apoptosis signaling pathways. Prog Neurobiol. 2006; 79:173-189.

54. Crowder RJ, Freeman RS. Glycogen synthase kinase- 3 beta activity is critical for neuronal death caused by inhibiting phosphatidylinositol 3-kinase or Akt but not for death caused by nerve growth factor withdrawal. J Biol Chem. 2000; 275:34266-34271.

55. Song L, De Sarno P, Jope RS. Central role of glycogen synthase kinase-3beta in endoplasmic reticulum stressinduced caspase-3 activation. J Biol Chem. 2002; 277:44701-44708.

56. Grassilli E, Narloch R, Federzoni E, Ianzano L, Pisano F, Giovannoni R, Romano G, Masiero L, Leone BE, Bonin S, Donada M, Stanta G, Helin K, Lavitrano M. Inhibition of GSK3B bypass drug resistance of p53-null colon carcinomas by enabling necroptosis in response to chemotherapy. Clin Cancer Res. 2013; 19:3820-3831.

57. Vandenabeele P, Galluzzi L, Vanden Berghe T, Kroemer G. Molecular mechanisms of necroptosis: an ordered cellular explosion. Nat Rev Mol Cell Biol. 2010; 11:700-714.

58. Vanden Berghe $T$, Vanlangenakker N, Parthoens E, Deckers W, Devos M, Festjens N, Guerin CJ, Brunk UT, Declercq W, Vandenabeele P. Necroptosis, necrosis and secondary necrosis converge on similar cellular disintegration features. Cell Death Differ. 2010; 17:922-930.

59. Yan S, Yang X, Chen T, Xi Z, Jiang X. The PPARgamma agonist Troglitazone induces autophagy, apoptosis and necroptosis in bladder cancer cells. Cancer Gene Ther. 2014; 21:188-193.

60. Mishra P, Paramasivam SK, Thylur RP, Rana A, Rana B. Peroxisome proliferator-activated receptor gamma ligand-mediated apoptosis of hepatocellular carcinoma cells depends upon modulation of PI3Kinase pathway independent of Akt. J Mol Signal. 2010; 5:20.

61. Mishra P, Senthivinayagam S, Rangasamy V, Sondarva G, Rana B. Mixed lineage kinase-3/JNK1 axis promotes migration of human gastric cancer cells following gastrin stimulation. Mol Endocrinol. 2010; 24:598-607.

62. Pradeep A, Sharma C, Sathyanarayana P, Albanese C, Fleming JV, Wang TC, Wolfe MM, Baker KM, Pestell RG, Rana B. Gastrin-mediated activation of cyclin D1 transcription involves beta-catenin and CREB pathways in gastric cancer cells. Oncogene. 2004; 23:3689-3699.

63. Thylur RP, Senthivinayagam S, Campbell EM, Rangasamy V, Thorenoor N, Sondarva G, Mehrotra S, Mishra P, Zook E, Le PT, Rana A, Rana B. Mixed lineage kinase 3 modulates beta-catenin signaling in cancer cells. The Journal of biological chemistry. $2011 ; 286: 37470-37482$. 